\title{
A Review on Insect Pest Complex of Oats (Avena sativa L.)
}

\author{
Ritesh Kumar $^{1 *}$, Ishtiyaq Ahad ${ }^{1}$, Stanzin Dorjey $^{2}$, Uzma Arifie $^{1}$ and \\ Sheikh Aafreen Rehman ${ }^{1}$
}

${ }^{1}$ Division of Entomology, ${ }^{2}$ Division of Plant Pathology, Sher-e-Kashmir University of Agricultural Sciences and Technology of Kashmir, Wadura Sopore, 193201, Kashmir, India

*Corresponding author

\section{A B S T R A C T}

\section{Keywords}

Fodder, Oats, Pest,

Fluctuation,

Infestation.

Article Info

Accepted:

07 October 2017

Available Online:

10 December 2017
The oat (Avena sativa L.), is a species of cereal grain grown for human consumption as oatmeal and one of the most common uses is as livestock feed. Winter fodder scarcity is one of the major problems in feeding management for ruminants in India and other country. Some of the improved fodders are introduced at farmer's level but appropriate technology is not yet established. Moreover there is a risk of fluctuation in the production potential of such fodder due to insect pest and climatic variability across the location. Oats crops are heavily attacked by armyworm, cereal leaf beetle, cutworm, wheat aphid, plant bug, grasshopper, oat thrips, wireworm, cockchafer, fruit fly, and cyst nematode. This review endeavors to piece together all known information about the insect that attacked on oats.

\section{Introduction}

Oats rank sixth in the world cereal production statistics following wheat, maize, rice, barley and sorghum. It is an important livestock feed and is a good source of protein, fiber and minerals. This crop is considered to be a rich source of protein, equal to meat, milk, and egg protein. As food oats are mostly preferred in breakfast, moreover it is viewed by consumers as one of the wholesome, healthiest, natural food with the result there is rising global food demand for oats. Out of cereals, the highest amounts of $\beta$-glycan are found in barley and oats grains (Ahmad and Zaffar, 2014). It has wider adaptability because of its excellent growth habits, quick regrowth, and better yield potential and provides palatable, succulent and nutritious green fodder (Singh et al., 1989).It is cultivated in Punjab, Haryana, West Bengal, Jammu \& Kashmir, Himachal Pradesh, Uttar Pradesh, Madhya Pradesh, Rajasthan and Maharashtra. The total area covered under oats cultivation in the country is about 5 lakh ha. The crop occupies maximum area in Uttar Pradesh (34 per cent), followed by Punjab (20 per cent), Bihar (16 per cent), Haryana (9 per cent) and Madhya Pradesh (6 per cent) (Pandey and Roy, 2011).India ranks first among the major livestock holding countries having about $15 \%$ livestock population of the world, however, milk production of our country are about $17 \%$. Total livestock 
population of India is 512 million. The present availability of green fodder is about400 million tonnes projecting a deficit of $63.50 \%$ and that of dry fodder is around 466 million tonnes against the requirement of 609 million tonnes (Verma et al., 2016). The fodder production in India is insufficient to meet the requirements of growing livestock population and country faces a net deficit of $61.1 \%$ in green fodder, $21.9 \%$ in dry crop residues and $64 \%$ in feeds (Agarwal et al., 2008).

In agronomy, an insect is classified as a pest if the damage it causes to a crop is sufficient to reduce the yield or the quality of the harvested product by an amount that is unacceptable to the farmer (Dent, 2000). Injury is the effect of pest activities on host physiology, which is usually deleterious, while damage is a measurable loss host yield quantity or quality. Globally, all crop production practices are being highly challenged by biotic and abiotic stresses. Biotic stress especially insect pests and diseases cause devastating damage in terms of yield and quality. On average pests causes 20$37 \%$ yield losses worldwide which translating to approximately \$70billion annually (Pimentel et al., 1997).Various arthropods and nematodes cause damage to oats (Avena sativa L. and $A$. byzantino K.) plants throughout their life and no stage of the crop is free from damage. Crops can be affected from the seedling stage until the grain is harvested. Pests of oats are either polyphagous (damaging a wide range of plants) or oligophagous (feeding on only a few plant species) and it is very rare, any insect found to be monophagous to oats crop. Hundreds of arthropod species feed on oats cultivated in the USA and other countries. Low infestations of certain pests in cereals may stimulate growth and tillers, and actually increase yields (Southwood and Norton, 1973). Examples of such pests are the greenbug, Schizaphis graminum Rondani; the chinch bug, Blissus leucopterus leucopterus Say; and the cereal cyst nematode, Heterodera avenae Wollenweber; most oats pests are only occasional pests and cause economic damage sporadically when climatic conditions are favorable for outbreaks. Examples of occasional pests in the USA are the armyworm, Pseudaletiauni puncta Haworth; cutworms, Agrotis or Thogonia Morrison; Apamea amputatrix Fitch; Chorizogrotis auxiliaries Grote; Crymodes devoststor Brace; Euxoao chrogaster Guenee; Peridroma margoritosa Haw; cereal leaf beetle, Oulema melanopus L. and grasshoppers viz. Melanoplus spp and Schistocerca americana Drury (Young and Teetes, 1977). Armyworm, cutworm, wheat aphid, plant bug, grasshopper, oat thrips, wireworm, cockchafer, fruit fly are the most commonly attacking pest of oats crop (Lone et al., 2009) (Table 1).

\section{Sucking insect pests}

\section{Aphids}

Oats crop is invaded by different pests among which with specific agronomic importance. There are six species of aphids that damage oats crop. These species include Rhopalosiphum padi, Schizaphis graminurn, R. Maidis, Metopoliphiurn dirhodum, Sitobion avenae and Diuraphis noxia. Two of the species commonly known as Russian Wheat Aphid (D. noxia) and Bird Cherry-Oat Aphid (R. padi) are considered notorious for their direct and indirect losses. In favorable climate conditions they are reproducing in great number and cause significant damages to the crop by decreasing the yield (Vasilina et al., 2009). In addition to this some aphid species inject toxins during their feeding as well as transmit viral diseases (Maneva et al., 2008). 


\section{Bird cherry oat aphids}

Bird cherry oat aphids can saliently be characterized due to their high adaptive biological plasticity and transmission of viral diseases Barley yellow Dwarf (BYD) virus in particular (Stern, 1967). Bird cherry oat aphid is native to almost all over the world and is abundantly found in Northern Europe, North America, and New Zealand. Bird cherry oat aphid can adopt a number of species as an alternate host including oats, wheat, cereal and other grasses and even on species of families Juncaceae or and Cyperaceae (Rautapaa, 1970) with primary host being Bird Cherry (Prunus padus L.) and closely related tree species. Yield losses caused by Bird cherry oat aphid can vary greatly depending upon the time of infestation in relation to plant growth. It is one of the serious pests in wheat growing areas of the world due to:

Its longest span of presence from early spring to late autumn

Ability to overwinter as an egg and/or parthenogenetic individuals and

Vectoring the Barley yellow Dwarf (BYD) virus.

\section{Russian Wheat Aphid (RWA)}

Russian Wheat Aphid (RWA) is known to be a sporadic insect causing significant yield losses by spreading out from its origin. The center of origin for RWA is considered to be the central Asian mountains of Caucasus and Tian Shan. The specie could now be found in South Africa, Western United States, Central and Southern Europe and Middle East (Berzonsky et al., 2003).The RWA was first reported in South Africa in 1978 (Walters, 1984), in Mexico during 1980(Gilchrist et al., 1984), in United States in 1986 and Canadian
Prairie Provinces during 1988(Morrison et al., 1988). RWA is present in almost all significant wheat producing areas of the world except Australia (Hughes and Maywald, 1990). RWA attacks most of the cereals including wheat, barley, triticale, rye and oats. Alternate hosts for RWA are cool season (crested) and wheat grasses (Agropyron spp.). The economic impact of RWA include direct and indirect losses that have been estimated to be $\$ 893$ million in Western United states during 1987 to 1993(Morrison and Peairs, 1998) whereas $37 \%$ yield losses in winter wheat have been reported in Canadian Prairies (Butts et al., 1997). Direct losses have also been assessed as an increased input cost due to insecticides and indirect losses include reduced yield due to RWA infestation.

\section{Greenbug}

Schizaphis graminum Rondanior greenbug is a warm season perennial pest, causing substantial losses to cereal crops and wheat in particular. Greenbug was first reported on oats during early $20^{\text {th }}$ century and also has colonized successfully in sorghum during 1960 (Harvey and Hackerott, 1969). Greenbug is known to be originated from Virginia, North America (Hunter, 1909) with a contradictory report that it might have originated from Italy. Webster and Amosson (1995) reported 41\% dry land and 93\% irrigated area under wheat cultivation in Western US was infested with green bug. A notorious periodic outbreak during 1976 in Oklahoma caused estimated losses exceeding \$80 million (Starks and Burton, 1977). Large populations of greenbug shift onto sorghum during summer when wheat is harvested and colonize in masses. In absence of sorghum, they can shift to wild grasses which can rarely accommodate larger populations (Anstead et al., 2003). 


\section{Leafhoppers}

Leafhoppers are not normally considered of major importance in small grains, Oman (1949) believed that they sometimes cause appreciable grain and forage losses. They also transmit blue dwarf virus disease of oats. Many species of leafhoppers can cause damage to oats crops. Several of them are attracted to oats fields in the late fall or early spring, when small grains are the principal green plants. Some species stay only a short time, but others are able to breed and reproduce on these crops. Many leafhoppers can be found in oats throughout the winter in the southern part of the winter oat area of the USA. One of the most important species damaging oat is the yellow-headed leafhopper Carneocephala flaviceps Riley. This species is easily recognized by its bright yellow or orange head with two light spots on the vertex, and light green forewings; the underside of the abdomen ispale yellow and the borders of the abdomen are slightly reddish. The legs are pale yellow. This species is strongly attracted to light. It is extremely abundant in the southern part of the USA.

\section{Thrips}

Oats are mostly damage by thrips takes the form of white or silvery marks on leaves and ears caused by the cell contents being sucked out. Severe thrips feeding can result in withering of the shoot and shriveling of the grain (Lewis, 1973). He worked with sweepnetting and in wheat he found Limothrips cerealium, L. denticornis, Haplothrips aculeatus, Thrips (probably angusticeps), Frankliniella tenuicornis and Anaphothrips obscurus. In southern Sweden, all the abovementioned types of thrips were found while in central Sweden $F$. tenuicornis dominated, with $H$. aculeatus in second place. $L$. cerealium was not found in central Sweden and. S. graminum in oats was only found in Scania. Studies on thrips in Finland were carried out during 1960-1969 by Koppa (1970). Later investigated the abundance dynamics of cereal thrips with sweep netting and also systematic sampling of plants. They found $L$. cerealium, $L$. denticornis and $T$. angusticeps dominating in oats winter wheat, winter rye and winter and summer barley. $S$. graminum has only one generation. The larvae fall to the ground and develop to adults, which hibernate in the soil for one or two winters. After the soil temperature has risen to $13.5{ }^{\circ} \mathrm{C}$ at $30 \mathrm{~cm}$ depth, the adults begin to emerge from the ground. The adults prefer oats and the larvae feed in the panicle.

\section{Stem sawfly}

The stem sawfly of wheat, Cephuscinctus Norton (Hymenoptera: Cephidae), is a phytophagous insect of wheat and other cereal crops including barley, rye and triticale. It is of serious concern indifferent parts of world especially in northern hemisphere (Shanower and Hoelmer, 2004). The C. cinctusis considered to be a single specie; however differences in virulence have been detected due to genetic variability. Its larvae under different environmental conditions such as similar to North Dakota and Montana differed in duration of post diapause development that might be due to climatic variability. It is one of the major pests of spring wheat in USA. The cropping system like summer fallowing and strip cropping is the main reason to make sawfly as a potential pest causing significant losses. The historical background revealed that $C$. cinctusis indigenous to North America and it exhibits a relationship with Siberian species (Ivie and Zinovjev, 1996). Its spread in North America could have occurred due to transport of straw or crown from plants containing live larvae (Ivie, 2001). 
Table.1 Pest complex of oats with their status

\begin{tabular}{|c|c|c|c|c|c|c|c|}
\hline \multirow[t]{2}{*}{ Sr. No. } & \multirow[t]{2}{*}{ Common name } & \multirow{2}{*}{$\begin{array}{l}\text { Scientific } \\
\text { name }\end{array}$} & \multirow{2}{*}{$\begin{array}{l}\text { Family and } \\
\text { Order }\end{array}$} & \multicolumn{3}{|l|}{ Status } & \multirow{2}{*}{$\begin{array}{l}\text { Crop stage/Nature of damage or } \\
\text { parts where damage is caused }\end{array}$} \\
\hline & & & & 1999 & 2000 & 2001 & \\
\hline 1. & Army worm & $\begin{array}{l}\text { Mythimna } \\
\text { separata }\end{array}$ & $\begin{array}{l}\text { Noctuidae: } \\
\text { Lepidoptera }\end{array}$ & Minor & $\begin{array}{l}\text { Major/ } \\
\text { Sporadic }\end{array}$ & Minor & Leaves seedling, on tender grains \\
\hline 2. & Cut worm & $\begin{array}{l}\text { Agrotis } \\
\text { ipsilon }\end{array}$ & $\begin{array}{l}\text { Noctuidae: } \\
\text { Lepidoptera }\end{array}$ & Minor & Minor & Minor & Young seedling, foliage \\
\hline 3. & Wheat aphid & $\begin{array}{l}\text { Schizaphis } \\
\text { graminum }\end{array}$ & $\begin{array}{l}\text { Aphididae: } \\
\text { Homopterans }\end{array}$ & Minor & Minor & Minor & $\begin{array}{l}\text { Nymphs infesting foliage, sucking } \\
\text { sap }\end{array}$ \\
\hline 4. & Plant bugs & $\begin{array}{l}\text { Lecanium } \\
\text { viride }\end{array}$ & $\begin{array}{l}\text { Pentatomidae: } \\
\text { Heteroptera }\end{array}$ & Minor & Minor & Minor & $\begin{array}{l}\text { Adults infesting foliage, leaves, } \\
\text { ears and grains }\end{array}$ \\
\hline 5. & Grasshoppers & $\begin{array}{l}\text { Heiroglypus } \\
\text { banian }\end{array}$ & $\begin{array}{l}\text { Acrididae: } \\
\text { Orthoptera }\end{array}$ & Stray & Stray & Stray & Leaves and stem \\
\hline 6. & Oat thrips & $\begin{array}{l}\text { Stenothrips- } \\
\text { graminum }\end{array}$ & $\begin{array}{l}\text { Thripidae: } \\
\text { Thysanoptera }\end{array}$ & Stray & Stray & Stray & $\begin{array}{l}\text { Adults and nymphs infesting } \\
\text { foliage. }\end{array}$ \\
\hline 7. & Wire worms & $\begin{array}{l}\text { Agriotes } \\
\text { spp. }\end{array}$ & $\begin{array}{l}\text { Elateridae: } \\
\text { Coleoptera }\end{array}$ & Minor & Minor & Minor & Damaging roots inside soil. \\
\hline 8. & Cock chafers & $\begin{array}{l}\text { Melolantha } \\
\text { spp. }\end{array}$ & $\begin{array}{l}\text { Scarabeidae: } \\
\text { Coleoptera }\end{array}$ & Minor & Minor & Minor & $\begin{array}{l}\text { White grubs in soil eating roots, } \\
\text { destroying seedling. }\end{array}$ \\
\hline 9. & Fruit fly & $\begin{array}{l}\text { Oscinella } \\
\text { fruit }\end{array}$ & $\begin{array}{l}\text { Chloropidae: } \\
\text { Diptera }\end{array}$ & Minor & Minor & Minor & $\begin{array}{l}\text { Eating stem, popu. On leaves, } \\
\text { mostly apical part }\end{array}$ \\
\hline 10. & Cyst nematodes & $\begin{array}{l}\text { Heterodera } \\
\text { specie }\end{array}$ & $\begin{array}{l}\text { Heteroderidae: } \\
\text { Tylenchida }\end{array}$ & Minor & Stray & Minor & $\begin{array}{l}\text { Little popu. found in root } \\
\text { rhizosphere }\end{array}$ \\
\hline
\end{tabular}


The case of severe infestation of wheat stem sawfly (WSS) was recorded in1922 in Canada which was due to absence of natural enemies of the sawfly that could result a severe threat to food security. The outbreaks of WSS were short lived because host plants were immediately eliminated due to rust epidemics but the continuous development of rust resistant genotypes lead to progression development of WSS population. Strip farming to control soil erosion is another reason for dissemination of WSS from one field to another.

\section{Foliage insect pests}

\section{Surface grasshoppers}

Surface grasshoppers (Chrotogonus trachypterus and $C$. oxypterus) are widely distributed in the Orient and Africa. These grasshoppers are polyphagous and feed on a number of cultivated crops. The occurrence and abundance of the surface grasshopper, $C$. trachypterus on paddy was monitored by (Lanjar et al., 2002) in Dokri, Pakistan. In India, $C$. trachypterus is more common in the north, whereas, $C$. oxypterus occurs in the southern regions.

The surface grasshopper is a pest of pastures throughout the year. The common desert representative of the genus collected from western Rajasthan appeared to belong to $C$. trachypterus, being widely distributed on the ground (their habitat is the surface of the soil) and more frequently collected from nurseries, gardens and wheat and oats fields. It is distributed throughout the plains in India including Orissa, South Arcot, Madura, Coimbatore, Bellary, Madhya Pradesh and Rajasthan (Kevan, 1959). Akhtar (1971) examined nymphs and adults feeding on leaves by cutting germinating plants of cotton, wheat, paddy, oats, barley and others particularly in areas adjoining wastelands.

\section{Pod borer/American bollworm}

Helicoverpa is considered as the most damaging insect pests in Australian agriculture, costing approximately $\$ 225.2$ million per year to control (Clearly et al., 2006). This pest is considered as a major insect pest of both field and horticultural crops in many parts of the world (Fitt, 1989). The pest status is due to its broader host range of its larvae, its feeding preference for reproductive stages of plants; its high fecundity; its high mobility; and its ability to enter facultative diapauses and thus adapt to different climates. These characteristics make $H$. armigera particularly well adapted to exploit transient habitats, such as man-made ecosystems. Worldwide, $H$. armigera has been reported on over 180 cultivated hosts and wild species in at least 45 plant families (Venette et al., 2003). The larvae feed mainly on the flowers and fruit of high value crops, and thus high economic damage can the flowers and fruit of high value crops, and thus high economic damage can be caused at low population densities (Anonymous, 2007).

\section{Cereal leaf beetle}

Cereal leaf beetle, Oulemamelanopus is considered a major pest of small grains in Europe, Asia, and the United States. Since its introduction into Michigan, it has rapidly spread and is now found in most states south and east of North Dakota, as well as in Montana, Idaho, Utah, Wyoming, Nevada, Oregon, and Washington (Herbert et al., 2007). It feeds on numerous species of wild and cultivated grasses although preferences are shown for including oats, barley, and wheat, possibly because of increases in survival and development time (Wilson and Shade, 1966). Although adults feed on young small grain plants, their feeding typically does not affect yield. Larvae however, eat long strips of parenchyma tissue skeletonizing the 
leaf decreasing the plant's ability to photosynthesize (Buntin et al., 2004). Significant feeding injury in wheat gives the field a frosted appearance. This loss of photosynthetic ability can cause significant losses in yield or grain quality (Grant and Patrick, 1993). Losses are highly variable, and depend on infestation levels as well as the crop and the region with maximum losses of $40 \%$ (Buntin et al., 2004). In Virginia commercial wheat fields average $15 \%$ yield loss if cereal leaf beetle is left untreated. One possible reason for these large populations is poor establishment of introduced biological control agents leading to limited or no control. Poor establishment of these parasitoids may be attributed to several factors including management practices, with a key reason being the unnecessary and poorly timed use of pesticides.

\section{Soil borne insect pests}

Soil insects live in the soil, and the larvae feed on roots or underground portions of the stems of oats. Because they are hidden, many of the injurious forms may escape attention. Soil borne insects are posing threat in various crops and become very difficult to manage various soil borne insects has been reviewed under: Hayes (1925) observed that the white grubs, a large group of beetle larvae that live in the soil, are found throughout the world and feed on nearly all cultivated crops. They represent a large group of beetle larvae that live in the soil. More than 100 species have been described in the USA and Canada. White grubs are among the most destructive soil born insects. Injury to oats first appears as areas of dead or dying plants scattered throughout the field. Apart from white grubs, false wireworm larvae can cause injury to the kernel, the sprout, and the stem. The false wireworm does major damage to the seed and germinating seed, whereas the true wireworm feeds more on roots. In the winter oats area of the USA, the greatest injury occurs during dry falls. Oats may be sown in soil too dry for the seeds to germinate, and the larvae follow the drill rows eating the germ of many seeds before rainfall appeared germination. One larva can destroy a large number of kernels. Damage also is caused by larvae feeding on the tender sprout just as it is pushing out of the seed. Even after the seedling is established, the larva may cut the stem off below the surface of the soil immediately above the node where the permanent roots form (Wakeland, 1926). White grub activity above the ground is of short period only for the purpose of mating and feeding, while the rest of its life is spent inside the soil. Adult beetles generally start emerging from the soil after the pre-monsoon showers in May- June and continue emerging up-to September. The beetles feed on the foliage of many host plants viz., apricot, apple, pear, plum, robinia, kaithi and forest trees in order to gain the energy needed for reproductive development. Moreover, Hawkins (1936) stated that a large wireworm population is generally associated with severe injury, and that about 105 wireworms can destroy an oats crop. Wireworm injury to grain is often inconspicuous because of the large number of plants, and yet the loss may be considerable (Thomas, 1940). Although a little thinning of small grains may be overcome by additional tillering, the blank spaces left by the worm may be occupied by weeds. Wireworm injury appears as irregular spots in the field. Injury to young plants delays maturity, but later damage stimulates a heavy production of late tillers that do not head or are still green at harvest time. Walkden (1950) reported that several species of cutworm may injure oats, but only a few are very destructive. Among the most injurious on oats in the USA, are the army cutworm, Chorizagrotis auxilians Grote and the variegated cutworm, Peridroma margaritosa Haw. The red-backed cutworm, Euxoa ochrogaster Guenee; the pale western 
cutworm Agrotisor Thogonia Morr; the glassy cutworm, Crymodes devastator Brace, and the yellow-headed cutworm, Apamea amputatrix Fitch have at times caused serious damage to oats, especially in Canada (Gibson, 1915).

\section{Yield loss assessment}

Assessing crop losses due to pests is important in making decisions about pest management based on costs and benefits and in allocating resources to the most important pests. The crop consists of a group of plants and each individual plant is a plastic, dynamic system in which pests reduce the uptake of nutrients or water, reduce photosynthesis and interrupt transport within the plant to stores or reproductive parts. The plant can partly compensate for any loss by increased activity, changes in leaf area or shoot growth. Such compensation can be one of the reasons for the success of cereals as crops.

\section{References}

Agarwal, R.K., Kumar, S., Tripathi, R.K., Sharma, R.K. and Singh, K.A. 2008. Agroeconomic analysis of fodder based cropping system. Indian Journal of Fertilizers, 4(4): 121-31.

Ahmad, M. and Zaffar, G. 2014. Evaluation of oats (Avena sativa L.) genotypes for betaglucan, grain yield and physiological traits. Applied Biological Research, 16(1):1-3.

Akhtar, M. 1971. Laboratory feeding tests with Chrotogonus trachypterus Blanchard (Orthoptera: Acrididae). Pakistan Journal of Zoology, 3: 163-167.

Anonymous, 2007. CABI: Crop Protection Compendium Commonwealth Agricultural Bureau, International. http://www.cabicom pendium.org/

Anstead, J. A., Burd, J. D. and Shufran, K. A. 2003. Over-summering and biotype diversity of grains. Journal of economic Entomology, 68: 161-164.

Berzonsky, W. A., Herbert, W. O., Patterson, F. L., Ding, H., Peairs, F. B., Haley, S. D.,
Porter, D. R., Harris, M. O., Ratcliffe, R. H., Lamb, R. J., Mckenzie. R.I.H and Shanower TG. 2003. Breeding wheat for resistance to insects. Plant Breeding Reviews.2Bulletin. 108.

Buntin, G. D., Flanders, K. L., Slaughter, R. W. and De Lamar, Z. D. 2004. Damage loss assessment and control of the cereal leaf beetle (Coleoptera: Chrysomelidae) in winter wheat. Journal of Economic Entomology, 97: 374-382.

Butts, R. A., Thomas, J. B., Lukow, O. and Hill, B. D. 1997. Effect of fall infestations of Russian Hughes, R. and Maywald, G. 1990. Forecasting the favorableness of the Australian environment for the Russian wheat aphid, Diuraphis noxia (Homoptera: Aphididae), and its potential impact on Australian wheat yields. Bulletin Entomological Research, 80: 165-175.

Cleary, A. J., Cribb, B. W. and Murray, D. A. H. 2006. Helicoverpa armigera (Hubner): can wheat stubble protect cotton from attack. Australian Journal of Entomology,45: 1015.

Dent, D. 2000. Insect pest management. 2nd ed. CAB international. Wallingford, UK.

Fitt, G.P. 1989. The ecology of Heliothis species in relation to agro ecosystems. Annual Review of Entomology,34:17-52.

Gibson, E.H. 1915. The sharp-headed grain leafhopper. USDA Bulletin. 254. U.S. Government Printing Office, Washington, DC.

Gilchrist, L. I., Rodriguez-montessoro, R. and Burnett, P. A. 1984. The extent of Freestate

Grant, J. F. and C. R. Patrick. 1993. Distribution and seasonal phenology of cereal leaf beetle (Coleoptera: Chrysomelidae) on wheat in Tennessee. Journal of Entomological Science, 28: 363-369.

Harvey, T. L. and Hackerott, H. L. 1969. Recognition of a greenbug biotype injuriousto sorghum. Journal of Economic Entomology,62:776-779.

Hawkins, J.H. 1936. The bionomics and control of wireworms in Maine. Maine Agricultural Experiment Station. Bulletin, 381

Hayes, W.P. 1925. A comparative study of the history of certain phytophagous scarabaeid beetles. Kansas Agricultural Experiment 
Station Technical. Bulletin,16.

Herbert, D. A., Van Duyn, J. W., Bryan, M. D. and Karren, J. B. 2007. Cereal Leaf Beetle. In G. D. Buntin, K. S. Pike, M. J. Weiss, and J. A. Webster (eds.), Handbook of small grain insects. Entomological Society of America, Lanham, MD. Pp. 120.

Hughes, R. and Maywald, G. 1990. Forecasting the favorableness of the Australia environment for the Russian wheat aphid, Diuraphis noxia (Homoptera: Aphididae), and its potential impact on Australian wheat yields. Bulletin Entomological. Research, 80:165-175.

Hunter, S. J. 1909. The greenbug and its enemies. The University of Kansas Science Bulletin, 9: 1-163.

Ivie, M. A. 2001. On the geographic origin of the wheat stem sawfly (Hymenoptera: Cephidae): a new hypothesis of introduction from northeastern Asia. American Entomologist, 47: 84-97.

Ivie, M. A. and Zinovjev, A. G. 1996. Discovery of the wheat stem sawfly (Cephus cinctus Norton) (Hymenoptera: Cephidae) in Asia, with the proposal of a new synonymy. The Canadian Entomologist, 128: 347-348.

Kevan, D. K. Mc. E. 1959. A study of genus Chrotogonus Audinet servile 1839 (Orthoptera: Acridoidea: Pyrgomorphidae) V. A. revisional monograph to the Chrotogoniai. Public. Cult. Corns. Diam. Angola, 43: 11-299.

Koppa, P. 1970. Studies on the thrips species most commonly occurring on cereals in Finland. Annales Agriculturae Fenniae, 9: 191-265.

Lanjar, A.G., Talpur, M.A., Khuhro, R. D. and Qureshi, K. H. 2002. Occurrence and abundance of grasshopper species on rice. Pakistan Journal of Applied Science, 2: 763767.

Lewis, T. 1973. Thrips, their biology, ecology and economic importance. Academic Press London and New York.

Lone, G.M., Baba, Z. A., Wani, N. A., Mir, S. A., Malik, M. A. and Parveena, B. 2009. Determination of pest complex of oats Avena sativa (L.) var. Kent and their status. Indian Journal of Applied Entomology, 23(2): 140-144.

Maneva, V., Savova, T. and Marcheva, M. 2008.
Propagation and species composition of aphids infesting oats. $44^{\text {th }}$ Croatian and $4^{\text {th }}$ International Symposium on Agriculture Pp.581-58.

Morrison, W. P. and Peairs, F. B. 1998. Introduction: response model concept and economic of autumnal bionomics. Annual entomological Society of America,60:514516.

Morrison, W., Bxendale, F., Brooks, L., Burkhardt, C., Campbell, J., Johnson, Massey, W., Mcbride, D., Peairs, F., and Schultz, J. 1988. The Russian wheat aphid: a serious new pest of small grains in the Great Plains. Great Plains Agricultural Council Publication. p.5

Oman, P.W.1949. The Nearctic leafhoppers (Homoptera: Cicadellidae). Entomological Society of Canada Mem 3

Pandey, K.C. and Roy, A.K. 2011. Forage Crops Varieties. IGFRI Jhansi (India) Pp. 16-17.

Pimentel, D., Houser, J., Preiss, E., White, O., Fang, H., Mesnick, L., Barsky, T., Tariche, S., Schreck, J. and Alpert, S. 1997. Water resources: agriculture, the environment, and society. Bio Science, 47: 97-106.

Rautapaa, J. 1970. Preference of cereal aphids for various cereal varieties and species of Gramineae, Juncaceae and Cyperaceae. Annales agriculturae fenniae, 9: 261-211.

Schizaphisgraminum (Homoptera: Aphididae) populations on non-cultivated grass hosts. Environmental Entomology,32: 662-667.

Shanower, T. G. and Hoelmer, K. A. 2004. Biological control of wheat stem sawflies: past and future. Journal of Agricultural and Urban Entomology 21: 197-221.

Singh, V., Khokar, J. S., Joshi, Y. P. and Verma, S. S. 1989. Effect ofnitrogen, seed rates and methods of sowing on forage oats (Avena sativa L.). Forage Research, 15: 29-32.

Southwood, T.R.E. and Norton, G.A. 1973. Economic aspects of pest management strategies and decisions. Pp. 168-184. In P.W. Geier et al., (ed.) Insects: Studies in population management. Ecological Society of Australia, Canberra, Australia.

Starks, K. J. and Burton, R. L. 1977. Preventing greenbug outbreaks. USDA Pp. 309

Stern, V. M. 1967. Control of the aphids attacking barley and analysis of yield increases streak 
and Diuraphis noxia in Mexico. In: P. A. Burnett (ed.), Barley Yellow Dwarf, A Proceedings of a Workshop, CIMMYT, Mexico. Pp. 157-163.

Thomas, C.A. 1940. The biology and control of wireworms. Pennsylvania Agricultural Experiment Station Bulletin, p.392.

Vasilina, M., Todorka, S. and Marina, M. 2009. Original scientific paper Propagation and species composition of aphids infesting oats Institute of agriculture - Karnobat, Bulgaria, e- mail: maneva_ento@abv.bg 2Istitute of plant genetic resources " $\mathrm{K}$. Malkov" - Sadovo, Bulgaria.

Venette, R., Davis C. E. E., Zaspel, J., Heisler H. and M. Larson. 2003. Mini Risk Assessment Old World bollworm, Helicoverpa armigera Hubner [Lepidoptera: Noctuidae]. Cooperative Agricultural Pest Survey, Animal and Plant Health Inspection Service, US Department of Agriculture.

Verma, C., Thanki, J. D., Singh, D. and Chaudhari, S. N. 2016. Effect of nitrogen, bio-fertilizer and farm yard manure on yield and nutrient uptake in oat (Avena sativa 1.). The bioscan, 11(1): 499-501.
Wakeland, C. 1926. False wireworms injurious to dry-farmed wheat and a method of combating them. Idaho Agricultural Experiment Station Research Bulletin,6.

Walkden, H.H. 1950. Cutworms, armyworms and related species attacking cereal and forage crops in the Central Great Plains. USDA Circular. 849. U.S. Government Printing Office, Washington, DC.

Walters, M. C. 1984. Progress in Russian wheat aphid (Diuraphis noxia Mordw.) research in the Republic of South Africa. Tech. Commun. 191, Dept. Agriculture Republic of South Africa.

Webster, J. A. and Amosson, S. 1995. Economic impact of the green bug in the western United States: Great Plains Agriculture Council Publication.155:1992-1993.

Wilson, M. C. and Shade, R. E. 1966. Survival and development of larvae of the cereal leaf beetle, Oulema melanopa (Coleoptera: Chrysomelidae), on various species of Gramineae. Annals of the Entomological Society of America, 59: 170-173.

Young, W.R. and G.L. Teetes.1977. Sorghum entomology. Annual Review of Entomology, 22:193-218.

\section{How to cite this article:}

Ritesh Kumar, Ishtiyaq Ahad, Stanzin Dorjey, Uzma Arifie and Sheikh Aafreen Rehman. 2017. A Review on Insect Pest Complex of Oats (Avena sativa L.). Int.J.Curr.Microbiol.App.Sci. 6(12): 525-534. doi: https://doi.org/10.20546/ijcmas.2017.612.064 